\title{
Motif Kerja Generasi Muda Di Bidang Pertanian: Studi Fenomenologi Tentang Motif Kerja di Bidang Pertanian pada Kelompok Pemuda Tani di Kota Batu
}

\author{
Hamyana \\ hams.lodaya@gmail.com
}

Prodi Penyuluhan Pertanian, Sekolah Tinggi Penyuluhan Pertanian, Malang, Indonesia

\begin{abstract}
Tujuan penelitian ini adalah untuk mendeskripsikan motif individu pemuda tani dalam keterlibatannya terhadap perubahan minat kerja generasi muda pada bidang pertanian. Metode yang dipakai dalam menguraikan rumusan masalah pada penelitian ini adalah dengan menggunakan pendekatan fenomenologi. Objek yang diteliti adalah pemuda tani yang tergabung dalam kelompok karang taruna petani sayur dan buah di Kota Batu. Hasil penelitian ini menunjukan bahwa terdapat dua motif yang secara umum mendorong atau menghambat generasi muda dalam bekerja pada bidang pertanian yaitu moral-cultural base dan motif rasional-structural base. Berdasarkan motif moral-cultural base, bekerja di bidang pertanian dimaknai bukan sekadar persoalan rasional untung atau rugi, melainkan sebuah panggilan jiwa dan sebuah tanggung jawab moral yang harus diemban oleh mereka. Sedangkan berdasarkan motif rasional-structural base, bekerja di bidang pertanian dipahami sebagai sebuah pilihan di mana pilihan untuk memilih atau tidak memilih bekerja di bidang pertanian didasarkan pada seberapa besar pilihan tersebut memberikan keuntungankeuntungan baik secara ekonomi, sosial, maupun lingkungan.
\end{abstract}

Kata kunci: generasi muda; motif; pertanian

\section{Pendahuluan}

Studi komprehensif dari berbagai disiplin keilmuan membuktikan proses perkembangan ekonomi (baik dalam arti sempit industrialisasi maupun arti luas modernisasi) yang terjadi sejak Revolusi Industri di Inggris telah menimbulkan kemerosotan peranan masyarakat tradisional (golongan petani di perdesaan) yang semakin cepat. Akibatnya, ketika terjadi pertumbuhan ekonomi, peranan golongan petani semakin menurun dan sebagai gantinya, peranan masyarakat modern semakin meningkat. Ditinjau dari struktur perekonomian nasional, sektor pertanian menempati posisi yang penting dalam kontribusinya terhadap PDB dan penyerapan tenaga kerja. Sejak reformasi ekonomi tahun 1983, telah terjadi beberapa perubahan seperti rasio pengeluaran pemerintah untuk sektor pertanian terhadap PDB sektor pertanian. Indikator tersebut berdasarkan data dari World Bank telah mengalami penurunan dari $8.7 \%$ pada PELITA IV menjadi $5.5 \%$ pada PELITA $\mathrm{V}$, dan akhirnya menjadi sebesar $3.6 \%$ pada PELITA VI (Supriyati \& Suryani, 2006). Perubahan tersebut menyebabkan kemampuan sektor pertanian dalam menciptakan output, pendapatan dan nilai tambah cenderung menurun.

Berdasarkan hasil sensus pertanian tahun 2003, jumlah tenaga kerja pertanian di Indonesia pada tahun 2003 sebesar 83.6 juta orang. Akan tetapi, dari total tenaga kerja di sektor pertanian tersebut, ternyata tidak seluruhnya bekerja. Secara garis besar, jenis kegiatan dari tenaga kerja pertanian dibedakan menjadi tiga kelompok yaitu petani, buruh tani, dan buruh non pertanian. Distribusi tenaga kerja pertanian pada tahun 1983 terdiri dari jumlah tenaga kerja pertanian yang bekerja sebagai petani $67 \%$, buruh tani $21 \%$, dan buruh non pertanian sebesar $11 \%$. Tahun 2003, secara nasional proporsi petani menurun 
$60 \%$, proporsi buruh tani $25 \%$, sementara buruh non pertanian meningkat menjadi $15 \%$. Dengan demikian, nampak bahwa ada pergeseran yang cukup signifikan berupa penurunan proporsi petani dan peningkatan proporsi buruh tani serta buruh non pertanian. Hasil kajian Supriyati dan Suryani (2006) menunjukan bahwa ada pergeseran tenaga kerja dari pertanian ke non pertanian. Hasil kajian ini juga diperkuat oleh hasil kajian Malian, Mardianto, dan Ariani (2004) serta Rusastra dan Suryadi (2004).

Pergeseran tenaga kerja dari pertanian ke non pertanian menjadi indikasi bahwa ada pergeseran selera/preferensi kerja masyarakat pada bidang pertanian. Apabila dicermati tentang distribusi tenaga kerja pertanian khususnya dari segi usia, nampak bahwa komposisi pekerja sektor pertanian belakangan ini didominasi oleh pekerja yang berusia antara 25 hingga 44 tahun yakni sebesar $44.7 \%$. Hasil kajian Malian dkk. (2004) menunjukan bahwa selama kurun waktu dari tahun 1982 sampai dengan 2003 komposisi pekerja sektor pertanian berdasarkan usia telah mengalami pergeseran. Tahun 1982, pekerja sektor pertanian masih didominasi oleh pekerja yang berusia dibawah 30 tahun (38\%), sementara jumlah pekerja yang berusia 30-44 tahun berjumlah $32 \%$, 45-59 tahun $22 \%$, dan usia di atas 60 tahun sebesar 7.5\%. Dua dekade kemudian, komposisinya berubah yaitu jumlah pekerja yang berusia di bawah 30 tahun semakin menurun menjadi 26\%. Sementara itu, pekerja dengan usia 30 sampai 44 tahun, 45 sampai 59 tahun, dan di atas 60 tahun meningkat masing-masing menjadi sekitar $36 \%, 25 \%$, dan $12 \%$.

Kota Batu sebagai maskot kemajuan pertanian di Jawa Timur juga tidak terlepas dari krisis regenerasi petani. Fenomena migrasi atau pergeseran tenaga kerja dari sektor pertanian ke sektor non pertanian di Kota Batu ditengarai karena semakin memudarnya daya tarik sektor pertanian sebagai sebuah bidang pekerjaan yang mampu memberi jaminan kehidupan. Pada saat yang bersamaan, tuntutan alih fungsi lahan dalam rangka memenuhi kebutuhan hunian juga sangat tinggi. Saat ini, Kota Batu menjelma menjadi kota wisata yang berimplikasi pada meningkatnya permintaan hunian baik yang berupa perumahan maupun perhotelan. Hal ini berakibat semakin berkurangnya lahan-lahan produktif yang bisa digunakan sebagai lahan usaha tani. Lahan-lahan tersebut kemudian dialihfungsikan menjadi klaster perumahan, perkantoran, dan area perhotelan.

Berdasarkan paparan data tersebut, dapat disimpulkan bahwa pekerja di sektor pertanian didominasi oleh pekerja yang terkategori pada golongan usia tua (di atas 31 tahun). Sementara pekerja pada golongan usia muda (di bawah usia 30 tahun) dari tahun ke tahun terus mengalami penurunan. Dengan kata lain, ada indikasi penurunan minat khususnya generasi muda untuk bekerja pada bidang pertanian. Akan tetapi, untuk membuktikan dugaan ini tentunya perlu pembuktian ilmiah melalui penelitian ilmiah. Berdasarkan latar belakang dan batasan fokus penelitian yang telah dipaparkan tadi, maka dapat dirumuskan pertanyaan pokok penelitian (research question) yaitu "Alasan-alasan apa yang melatarbelakangi pemuda tani di Kota Batu untuk memilih atau tidak memilih bekerja dibidang pertanian?"

Berdasarkan pertanyaan penelitian yang telah dikemukakan di atas, maka secara lebih rinci penelitian ini memfokuskan perhatian pada pertanyaan: "Bagaimana motif dan dinamika psikologis individu pemuda tani 
dalam keterlibatannya terhadap perubahan minat kerja generasi muda pada bidang pertanian? Adapun tujuan penelitian ini difokuskan untuk menganalisis hubungan timbal balik dari perubahan preferensi kerja dengan sistem ekonomi, pranata sosial, dan stratifikasi masyarakat. Secara lebih rinci tujuan penelitian adalah untuk mendeskripsikan motif individu pemuda tani dalam keterlibatannya terhadap perubahan minat kerja generasi muda pada bidang pertanian.

\section{Metode}

\section{Jenis dan pendekatan penelitian}

Penelitian ini menggunakan metode kualitatif yang dirancang dalam kerangka pendekatan fenomenologi.

\section{Lokasi penelitian}

Penentuan lokasi penelitian dilakukan secara purposive yaitu di Kota Batu. Terdapat beberapa pertimbangan dalam memilih Kota Batu sebagai lokasi penelitian di antaranya adalah:

1. Kategori penduduk Kota Batu secara umum terbagi atas petani, buruh tani, dan buruh non pertanian. Data menunjukan bahwa proporsi petani dan buruh tani Kota Batu mencapai 58\%. Akan tetapi, tenaga kerja pertanian yang ada Kota Batu berada pada kategori umur tua (>40 tahun).

2. Pengamatan sementara menunjukan adanya indikasi bahwa generasi muda yang ada Kota Batu lebih memilih untuk tidak bekerja pada bidang pertanian dan beralih pada sektor buruh non pertanian. Padahal dari aspek ketersediaan lahan dan pasar cukup tersedia.

3. Konsep agrowisata yang dicanangkan dalam beberapa tahun terakhir telah membawa konsekuensi pada tingginya jumlah pengunjung yang datang ke Kota Batu. Hal ini berdampak pada meningkatnya permintaan jasa akomodasi. Padahal di sisi lain, ketersediaan lahan untuk permukiman semakin terbatas.

4. Selama kurun waktu 20 tahun terakhir, Kota Batu telah bertransformasi menjadi kawasan permukiman baru yang mana hampir $30 \%$ dari total lahan pertanian produktif telah beralih fungsi menjadi area permukiman dan perkantoran baru (hotel, perumahan, perkantoran, dan pertokoan).

\section{Teknik penentuan informan}

Penentuan informan kunci ditentukan secara purposive, yaitu orang yang dianggap mengerti dan memahami permasalahan yang diteliti dalam jangka waktu yang lama dan sekaligus mampu membantu peneliti dalam menggali data di lapangan. Teknik penentuan informan dilakukan melalui dua tahap. Pertama, menentukan tipikal grup yang diduga representatif. Kedua, secara purposive akan dipilih 35 orang pemuda yang mewakili stratifikasi pada struktur pemuda yang ada di Kota Batu, khususnya yang berasal dari karang taruna. Penelusuran informan dilakukan sampai data yang dikaji cukup dan menggambarkan realitas yang ada di lapangan.

\section{Teknik pengumpulan data}

Mengacu pada pemikiran Creswell (2010), teknik pengumpulan data dalam penelitian fenomenologi adalah sebagai berikut:

\section{Wawancara mendalam}

Wawancara dilakukan terhadap individu yang menjadi informan yang sengaja dipilih dengan memperhatikan kriteria tertentu. Dalam melakukan wawancara, peneliti terlebih dahulu membuat kisi-kisi wawancara 
yang ditetapkan berdasarkan topik utama penelitian ini yakni terkait motif kerja generasi muda untuk memilih bekerja di bidang pertanian. Wawancara mendalam dilakukan sampai terdapat kejenuhan informasi dari informan satu dengan informan lainnya.

\section{Observasi}

Observasi dilakukan dalam rangka memperdalam pemahaman peneliti terkait konteks penelitian yang dihasilkan ketika proses wawancara. Pada konteks ini, yang akan dilakukan adalah mengobservasi karakteristik sosial masyarakat khususnya pemuda di Kota Batu dalam keterkaitannya dengan bidang pertanian.

\section{Studi dokumen}

Dokumen-dokumen yang ditengarai memiliki relevansi dengan konteks penelitian akan sangat menunjang dalam memperdalam pemahaman peneliti secara komprehensif. Oleh karena itu, studi dokumen juga memegang peranan yang sangat penting dalam aktivitas penelitian fenomenologi.

\section{Keabsahan data}

\section{Kredibilitas data}

Untuk memenuhi keabsahan data tersebut, maka akan digunakan dua teknik dari Lincoln dan Guba (1985), yaitu sebagai berikut:

1. Triangulation, merupakan teknik yang mengumpulkan berbagai data mengenai perubahan pola kehidupan sosial ekonomi masyarakat desa yang menyertai industrialisasi yang terjadi untuk kemudian dibandingkan antara sumber data satu dengan yang lain. Pada penelitian ini akan dilakukan triangulasi antara wawancara mendalam, observasi, dan studi dokumen.

2. Member check, merupakan upaya peneliti untuk melibatkan sebagian informan untuk mengonfirmasikan data-data serta interpretasinya termasuk dengan teman sejawat dalam rangka memelihara kredibilitas data.

\section{Dependabilitas}

Kriteria ini dipakai untuk menjaga kehati-hatian sehingga dapat dihindari kemungkinan terjadinya kesalahan dalam mengumpulkan dan menginterpretasi data.

\section{Konfirmabilitas}

Hampir sama dengan kegiatan dependabilitas yang menekankan kehati-hatian dalam menjaga dan menilai hasil penelitian dengan mengonsultasikan kepada pihak yang berkompeten dalam melakukan penelitian hasil studi kualitatif.

\section{Metode analisis data}

Creswell (2010) mengemukakan teknik analisis dan representasi data yang agak berbeda untuk penelitian fenomenologi sebagaimana disampaikan pada Tabel 1 .

\section{Hasil dan Diskusi}

\section{Motif moral dan kultural pemuda tani di kota batu dalam memaknai kerja dibidang pertanian}

Pemaknaan seorang individu terhadap suatu fenomena sosial akan berimplikasi pada aktualisasi tindakan yang dilakukan oleh individu tersebut. Begitu halnya dengan generasi muda (pemuda tani) di Kota Batu. Sebagaimana diungkapkan oleh Scott (1993) bahwa kehidupan petani (peasant) adalah masyarakat yang harmoni dan stabil. Komunitas petani adalah suatu kelompok sosial yang memiliki kepentingan untuk menjaga kelangsungan keterikatan antar individunya. Mereka adalah masyarakat yang "mendahulukan selamat". Scott (1993) juga 
menyampaikan bahwa pilihan tindakan manusia tidak terlepas dari entitas lain yang berada disekitarnya. Seseorang akan menolak atau menerima suatu realitas yang kemudian diaktualisasikan dalam perilaku sehari-hari mereka sangat bergantung pada bagaimana mereka mampu memodifikasi dan menginterpretasi dari berbagai makna dan simbol yang diterimanya.

Tabel 1

Teknik Analisis dan Representasi Data Penelitian Fenomenologi

\begin{tabular}{|c|c|}
\hline $\begin{array}{c}\text { Analisis dan } \\
\text { Representasi Data }\end{array}$ & Penelitian Fenomenologi \\
\hline Pengolahan data & $\begin{array}{l}\text { Membuat dan mengorganisaikan } \\
\text { data }\end{array}$ \\
\hline $\begin{array}{l}\text { Membaca dan } \\
\text { mengingat data }\end{array}$ & $\begin{array}{l}\text { Membaca teks, membuat batasan- } \\
\text { batasan catatan, dan membuat } \\
\text { formulir kode-kode inisial }\end{array}$ \\
\hline Menggambarkan data & $\begin{array}{l}\text { Menggambarkan makna dari } \\
\text { peristiwa untuk peneliti }\end{array}$ \\
\hline Mengklsifikasikan data & $\begin{array}{l}\text { - Menemukan pertanyaan- } \\
\text { pertanyaan bermakna dan } \\
\text { membuat daftarnya } \\
\text { - Mengelompokkan pertanyaan- } \\
\text { pertanyaan yang sama ke dalam } \\
\text { unit-unit makna tertentu. }\end{array}$ \\
\hline Interpretasi data & $\begin{array}{ll}\text { - } & \text { Membangun deskripsi tekstural } \\
\text { (apa yang terjadi) }\end{array}$ \\
\hline $\begin{array}{l}\text { Visualisasi dan } \\
\text { presentasi data }\end{array}$ & $\begin{array}{l}\text { Narasi esensi peristiwa dilengkapi } \\
\text { dengan tabel pertanyaan dan unit- } \\
\text { unit makna }\end{array}$ \\
\hline
\end{tabular}

Fakta dan realita enggannya para pemuda untuk bekerja di bidang pertanian bisa dimaknai sebagai sebuah tindakan resistensi atau perlawanan mereka terhadap kalangan elit yang terus menerus dengan gencarnya menebar pesona modernisasi dan westernisasi pada hampir semua sendi kehidupan. Ada kecenderungan yang nampak bahwa resistensi terhadap pertanian oleh generasi muda bukan hanya sekedar persoalan untung atau rugi, melainkan ada persoalan nilai dan identitas yang semakin melenceng jauh dari rel yang seharusnya. Nilai-nilai yang diusung oleh kapitalisme modern yang memupuk dengan begitu suburnya sifat-sifat hedonisme, gaya hidup instan, individualis, nampaknya secara sadar atau tidak, terus diinternalisasi pada generasi muda sekarang ini. Pada sisi lain, nilai-nilai asketis, gotong-royong, dan tenggang rasa yang merupakan nilai-nilai luhur yang diwariskan oleh orang tua dan nenek moyang bangsa Indonesia perlahan tapi pasti mulai bergeser, memudar, bahkan terkikis habis oleh derasnya hempasan modernisasi dan kapitalisasi.

Pergulatan antara nilai-nilai west dan nilai-nilai tradisional yang ada dimasyarakat nampaknya tidak akan segera berkesudahan. Implikasi dari adu kuat nilai - nilai west dan nilai-nilai tradisional salah satunya adalah enggannya atau tidak berminatnya sebagian besar generasi muda untuk bekerja dibidang pertanian. Hal ini disebabkan oleh hadirnya pemaknaan yang dikontruksi oleh generasi muda tentang pertanian sebagai sebuah pekerjaan yang kotor, dekil, tidak modern, bahkan nilai gengsinya lebih rendah dari profesi tukang ojek sekalipun. Internalisasi westmemang belum merasuki semua individu, akan tetapi jika fenomena ini terus dibiarkan tentu saja akan mengancam jati diri sebagai bangsa yang ramah, solid, dan arif.

Ada fakta menarik yang ditemukan pada beberapa generasi muda yang masih bertahan dengan kecintaanya terhadap dunia pertanian ketika di saat yang bersamaan orang lain sudah tidak lagi tertarik untuk berkecimpung di bidang tersebut. Bagi mereka, fenomena modernisasi dan westernisasi tidak bisa dibiarkan terus tumbuh dan berkembang. Harus ada sebuah aksi resistensi supaya terus 
bisa eksis pada kehidupannya. Bekerja di bidang pertanian bukan lagi sebagai persoalan rasional untung atau rugi, melainkan sebuah panggilan jiwa, sebuah tanggung jawab moral yang harus diemban oleh mereka sebagai generasi penerus pembangunan. Pengertian tanggung jawab moral yang dimaksud oleh informan adalah bahwa semua manusia di dunia ini masih mengandalkan kebutuhan makanan pokoknya dari sektor pertanian. Beras, singkong, jagung, sagu, dan lainnya adalah contoh beberapa komoditas makanan pokok yang dihasilkan oleh sektor pertanian. Jika tidak ada lagi yang berminat untuk bekerja pada sektor pertanian, lantas siapakah yang akan menyediakan kebutuhan bahan pokok tersebut. Berdasarkan landasan pemikiran itulah muncul rasa tanggung jawab moral informan untuk tetap bertahan di sektor pertanian, walaupun dengan segala macam resikonya.

Pilihan tindakan tersebut di atas tentu saja tidak hadir dengan seketika, melainkan melalui proses modifikasi makna dan simbol yang terjadi pada seorang individu untuk merekontruksi dan melawan sebuah introduksi dan internalisasi oleh pihak lainnya. Tindakan inilah yang kemudian oleh peneliti disebut sebagai aksi resistensi generasi muda terhadap nilai-nilai westernisasi dan modernisasi. Motif perilaku resisten oleh komunitas ini didasari oleh kesadaran yang bersifat emosional yang memandang bahwa bekerja di bidang pertanian lebih dari sekedar persoalan ekonomi atau persoalan rasional untung dan rugi, akan tetapi bekerja di bidang pertanian didorong oleh kesadaran moral dan kultural. Maksud kesadaran moral adalah bahwa tanggung jawab individu setiap manusia untuk memberikan manfaat bagi sesama, oleh pemuda tani yang masih bekerja di bidang pertanian di Kota Batu, diimplementasikan dalam bentuk pengabdian mereka dalam menyediakan sumber-sumber pangan untuk masyarakat melalui aktivitas budidaya pertanian. Citra bahwa pertanian bukan sebuah pekerjaan yang menguntungkan, kotor, dan pekerjaan yang tidak kekinian bukanlah sebuah masalah bagi komunitas ini. Bahkan sebaliknya, motif moral melihat bahwa bertani merupakan sebuah pengabdian, sebuah jalan hidup menuju surga. Bertani adalah sebuah pilihan terbaik dari yang baik dalam memberikan darma bakti hidup ini di dunia.

Menurut Scott (1993) resistensi merupakan semua tindakan dari anggota masyarakat kelas bawah dengan maksud untuk mempertahankan kelangsungan hidupnya. Para petani melakukan resistensi atau melakukan perlawanan mempertahankan diri karena terpaksa untuk mempertahankan hidup. Perjuangan yang dilakukan para petani ini merupakan perjuangan yang biasa namun dilakukan terus menerus. Hal yang menarik dari konsep ini adalah resistensi hanya bersifat individual atau tidak bersifat kolektif. Ada 3 kategori resistensi yang bisa dilakukan. Pertama, bersifat individual, spontan, dan tidak terorganisasi. Kedua, tujuan resistensi agar ada reaksi dari pihak yang dilawan. Ketiga, resistensi ini bersifat ideologis atau mengarah pada resistensi simbolis. Berbeda dengan perjuangan yang bersifat frontal, resistensi adalah penolakan terhadap sesuatu yang tidak bisa dilawan. Sifat resistensi itu sendiri adalah informal, tersembunyi, dan tidak teratur.

Scott (2008) juga menjelaskan bahwa perubahan lingkungan yang membuat masyarakat petani melakukan resistensi. Penetrasi kekuatan pemodal yang menyebabkan transformasi budaya dalam kehidupan desa mendorong para petani melakukan resistensi. Hal ini menunjukkan 
bahwa para petani yang digambarkan sebagai pihak yang lemah memiliki senjata dalam melawan kaum pemodal berupa perusakan, masa bodoh, kejahatan, sabotase, dan bahkan pada akhirnya enggan untuk bekerja di bidang pertanian. Dalam hal ini, resistensi didasari moral ekonomi petani ketika ada suatu "aturan" yang mengancam kehidupan mereka. Konsep hegemoni ini menyatakan bahwa pemodal menjepit kehidupan petani.

Scott (1993) mengemukakan bahwa untuk menyelamatkan diri dari struktur kehidupan mereka, masyarakat petani pedesaan menjalani gaya hidup gotong royong, tolong menolong, dan melihat sejumlah persoalan yang dihadapi sebagai persoalan kolektif serta pembagian hasil sama rata. Intensifikasi pertanian berupa komersialisasi hasil-hasil pertanian merupakan ancaman bagi para petani, yang akan mengakibatkan petani meninggalkan desa dan kemudian menjadi pengangguran di kota. Dalam kenyataan sehari-hari, apa yang dialami kaum petani sebagaimana digambarkan tersebut juga terjadi di antara warga masyarakat, seperti situasi perekonomian yang memburuk, PHK (pemutusan hubungan kerja), tuntutan keluarga, atau anak sakit sementara masyarakat berdiam diri. Tindakan perlawanan terhadap dominasi yang menghimpit dapat dilihat dari penipuan, penggelapan uang tetangga, atau mencuri yang jauh dari prinsip moral mereka. Namun karena mekanisme sosial dalam menghadapi kondisi sehari-hari yang menghimpit mereka maka tindakan tersebut berjalan terus. Perlawanan sehari-hari juga dapat dilihat dari pemberian nama ejekan, ngutil, berbohong, sabotase bahkan perlawanan yang tidak dapat dilihat oleh lawan mereka sendiri seperti kecenderungan bunuh diri.

\section{Motif rasional dan struktural pemuda tani di Kota Batu dalam memaknai kerja di bidang pertanian}

Teori rasional berasumsi bahwa setiap manusia pada dasarnya rasional dengan selalu mempertimbangkan prinsip efisiensi dan efektifitas dalam melakukan setiap tindakan. Dengan tetap mengakui adanya faktor determinan berupa solidaritas masyarakat petani yang kuat, subsistensi perekonomian (material), dan hubungan produksi masyarakat prakapitalis, namun pengaruh rasionalitas selalu terjadi dalam konteks beroperasinya mekanisme kepentingan rasional individu anggota komunitas. Manusia memang cenderung memaksimalkan rasionalitasnya dan selalu cenderung menghitung nilai sesuatu (utility) yang hendak dipertukarkan, yaitu economic dan moral utility (Alfred, 1987).

Perilaku pemuda di Kota Batu yang sebagian besar enggan untuk bekerja di bidang pertanian dapat dimaknai sebagai sebuah upaya yang rasional dalam rangka menjaga eksistensi mereka. Pandangan beberapa informan terhadap sektor pertanian menunjukan bahwa pekerjaan petani dicitrakan sebagai sebuah pekerjaan yang tidak mampu memberikan jaminan masa depan yang baik. Pandangan ini dilandasi oleh perhitungan ekonomis di mana secara kalkulasi ekonomi, jika hanya bertani secara konvensional pada skala usaha yang sempit (kurang dari $0.5 \mathrm{ha}$ ), maka belum mampu memberikan hasil yang bisa menghidupi rumah tangga petani. Kondisi tersebut diperparah dengan kurang berpihaknya kebijakan pemerintah dalam melindungi petani misalnya terkait dengan fluktuasi harga, jaminan keamanan produksi (asuransi), dan perlindungan atas hak pengugunaan lahan. Potret pertanian yang buram dalam pandangan individu yang rasional secara ekonomi tentu saja bekerja 
pada sektor pertanian bukanlah sebuah pilihan yang logis. Desa dan para petani bukan hanya dilihat sebagai sebuah "komunitas" tetapi sebuah korporasi yang melihat adanya hubungan transaksional yang mengarah pada eksploitasi bukan hubungan paternalistik.

Mengacu pada teori pilihan rasional (Coleman, 1990), terdapat ide dasar bahwa orang-orang bertindak secara sengaja ke arah suatu tujuan dan tujuan itu dibentuk oleh nilainilai atau pilihan-pilihan. Para aktor akan melakukan tindakan-tindakan dalam rangka memaksimalkan manfaat, keuntungan serta pemuasan pada kebutuhan-kebutuhan mereka. Oleh karena itu, terdapat dua unsur yang harus ada dalam teori ini yaitu aktor dan sumber daya. Sumber daya yang dimaksud tentu saja harus dapat dikontrol oleh sang aktor. Interaksi mereka selanjutnya dapat mendorong pada level sistem yang menghubungkan isu mikromakro (Ritzer \& Smart, 2012).

Terdapat beberapa contoh kasus yang digunakan oleh Coleman (1990) untuk memerjelas bagaimana teori pilihan rasoinal bekerja. Pertama adalah perilaku kolektif, yaitu isu mikro yang dapat dilihat dari sisi mikro individu pelakunya. Munculnya perilaku kolektif karena aktor menilai perlunya menyandarkan kepentingan atau tujuannya kepada individu lain agar mendapat keuntungan yang maksimal tanpa harus malakukan usaha yang besar. Kedua adalah norma-norma dalam kelompok sosial, yang merupakan upaya yang dilakukan oleh aktor agar individu lain mengontrol kendali dari aktor agar efektifitas menjadi meningkat dan memunculkan konsensus yang mencegah ketidakseimbangan. Ketiga adalah aktor korporat, yang kemunculannya merupakan upaya dari kelompok sosial untuk mendorong sang aktor secara bersama-sama. Ketika aktor berkompetisi dalam pemilihan, misalnya, maka proses pemungutan suara individuindividu adalah isu mikro menuju makro.

Penekanan pada pandangan bahwa individu adalah homo sociologicus mendorong perspektif pilihan rasional pada proses sosialisasi yang akrab di antara individu dan masyarakat. Kontrasnya, homo economicus dalam pandangan ini harus diperjelas. Ini semua merupakan upaya untuk menyerang teori sosial tradisional yang hanya melantunkan mantra-mantra yang sudah tidak relevan dalam perjalanan perubahan masyarakat saat ini (Ritzer \& Smart, 2012).

Ada tiga kritikan yang muncul dari teori ini. Pertama, terlalu berlebihan dalam memberi perhatian pada hubungan masalah mikromakro dan sedikit mengabaikan hubungan yang lain. Kedua, mengabaikan hubungan makro-makro. Ketiga, hubungan sebab akibatnya hanya menuju pada satu arah, dengan kata lain dia mengabaikan dialektika di kalangan fenomena mikro-makro (Ritzer \& Smart, 2012).

Dengan demikian, dapat disimpulkan bahwa. Berdasarkan motif moral-cultural base, bekerja kerja di bidang pertanian dimaknai bukan sekedar persoalan rasional untung atau rugi, melainkan sebuah panggilan jiwa, sebuah tanggung jawab moral yang harus diemban oleh mereka sebagai generasi penerus pembangunan dalam melawan dominasi dan hegemoni paham modernisme, hedonisme, dan westernisasi yang menurut mereka ide dan gagasannya tidak seirama dengan nilai-nilai luhur yang dibangun oleh nenek moyang mereka.

Sedangkan berdasarkan motif rasionalstructural base, bekerja di bidang pertanian dipahami sebagai sebuah pilihan yang 
didasarkan pada seberapa besar pilihan tersebut memberikan keuntungan-keuntungan baik secara ekonomi, sosial, maupun lingkungan. Bagi sebagian generasi muda, bekerja di bidang pertanian tidak lagi dilihat sebagai pilihan terbaik dalam memberikan keuntungan-keuntungan dalam kehidupan mereka. Oleh karena itu, banyak pul di antaranya yang beralih dari profesi petani menjadi profesi yang lain, misalkan sebagai staf di sebuah hotel, atau sebuah perkantoran. Namun demikian, dalam kurun waktu tiga tahun terakhir ini, fakta menunjukan bahwa citra pertanian menunjukan tren positif seiring dengan dicanangkannya Kota Batu sebagai kota agropolitan yang berwawasan lingkungan.

\section{Daftar Pustaka}

Alfred, M. (1987). Principles of Economics An Introductory Volume. London: Macmillan.

Coleman, J. S. (1990). Foundations of Social Theory. London: Harvard University Press.

Creswell, J. (2010). Pendekatan Kualitatif, Kuantitatif, dan Mixed Edisi Ketiga (Terjemahan). Yogyakarta: Pustaka Pelajar.

Lincoln, Y. S. \& Guba, E. B. (1985). Naturalistic Inquery. Beverly Hills: Sage Publications.

Malian, H. A., Mardianto, S., \& Ariani, M. (2004). Faktor-faktor yang memengaruhi produksi, konsumsi, dan harga beras serta inflasi bahan makanan. Jurnal Agro Ekonomi, 22(2), 119-147.

Ritzer, G., \& Smart, B. (2012). Handbook Teori Sosial (Terjemahan). Bandung:
Nusa Media.

Rusastra, I. W., \& Supriyadi, M. (2004). Ekonomi tenaga kerja pertanian dan implikasinya dalam peningkatan produksi dan kesejahteraan buruh tani. Jurnal Litbang Pertanian, 23(3), 91-99.

Scott, J. C. (1993). Perlawanan Kaum Tani (Terjemahan). Jakarta: Yayasan Obor Indonesia.

Scott, R. W. (2008). Institutions and Organizations: Ideas and Interest. London: Sage Publication.

Supriyati, \& Suryani, E. (2006). Peranan, peluang, dan kendala pengembangan agroindustri di Indonesia. Forum Penelitian Agro Ekonomi, 24(2), 92-106. 